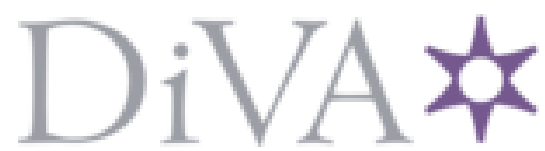

http://www.diva-portal.org

\title{
Postprint
}

This is the accepted version of a chapter published in Theoretical perspectives on family businesses.

Citation for the original published chapter:

Wielsma, A. (2015)

Corporate reputation and the family business.

In: Mattias Nordqvist, Leif Melin, Matthias Waldkirch and Gershon Kumeto (ed.), Theoretical perspectives on family businesses (pp. 233-252). Cheltenham: Edward Elgar Publishing https://doi.org/10.4337/9781783479665.00020

N.B. When citing this work, cite the original published chapter.

Permanent link to this version:

http://urn.kb.se/resolve?urn=urn:nbn:se:hj:diva-34248 


\section{Corporate Reputation and the Family Business}

\section{Albertha Wielsma}

\section{Introduction}

A favourable corporate reputation is generally accepted to be a major source of competitive advantage. Numerous scholars in this field have established reputation's positive effects on, for instance, sales, consumer loyalty and employee attraction (Barnett, Jermier \& Lafferty, 2006; Cornelissen, 2011; Van Riel, 2012). Despite this confirmation, very few studies on family firms focus on the reputation of family firms, either in general or for specific firms. An internet search for articles with the word 'family' combined with either 'business' or 'firm' and either 'reputation' or the related word 'image' in the title reveals only 12 articles that have family firm reputation or image as their apparent topic of interest. Further, of all of the articles published in Corporate Reputation Review, a leading journal on this topic, not one focuses on family businesses. This lack is surprising because the characteristics that are considered to be central to family firms by most scholars (e.g., family ownership and involvement, long term or transgenerational orientation) provide many clues to the study of family firm reputation. Examples of these characteristics are the strong identity overlap between family and firm (e.g., Dyer $\&$ Whetten, 2006), the interaction effects between family reputation and firm reputation, and also the important topic of succession. Family firm studies that do consider reputation mostly treat the family's concern for reputation as an explanatory factor for firm behaviour that is difficult to explain otherwise (e.g., Zellweger, Nason, Nordqvist \& Brush, 2011; Gomez-Mejia, Cruz, Berrone \& De Castro, 2011) or they focus on corporate marketing strategies (e.g., Blombäck \& Botero, 2013; Micelotta \& Raynard, 2011). Although these studies clearly show the relevance of the reputational lens for the study of 
family firms, the construct of reputation itself within the family firm context is seldom the topic of interest.

The primary purpose of this chapter is to demonstrate the potential of reputation research in the field of family business and to offer suggestions for future research. The chapter is structured as follows. In the next paragraph, I offer a very brief history of the study of reputation. In the third section, I summarise and synthesise the theoretical approach of reputation and the related construct of image. The fourth section is dedicated to reputation research in family firms. I provide an overview of the work to date on reputation and its related constructs. Directions for future research follow in the fifth section.

\section{Returning to the roots}

The word 'reputation' is derived from the Latin words 're', which means ‘again' or ‘repeatedly', and 'putare’, which means ‘counting or calculating'. Over the last three decades, economics, marketing, organisation theory, strategy, sociology, communications and accounting have contributed to the study of corporate reputation, each with their own perspective on this construct (Fombrun, Gardner \& Sever, 2000). As a result, there are various definitions of corporate reputation, treating it either as an 'awareness' of a firm by stakeholders or the general public, as an 'assessment' involving judgment, or as an 'asset' (Barnett et al., 2006). Organisational scholars, for instance, see reputation predominantly as an outcome of an organisation's identity. To marketers, reputations are assets that can attract new customers and bind existing customers to the organisation, while the field of accountancy approaches reputation as a form of goodwill that has a fluctuating market value (Fombrun, Gardner \& Sever, 2000). The field of corporate communication approaches reputation as a product of a company's efforts to communicate an authentic, unique and distinct corporate 
identity to stakeholders (Cornelissen, 2011). I will elaborate on the definitional issues in the next section.

The study of corporate reputation gained momentum in the 1990s. Barnett et al. (2006) show that the number of scholarly articles on this subject is five times greater in 2003 than in 1993. Still, at the beginning of this century, many reputation scholars state that the persisting lack of definitional clarity and the resulting variety in data hinders proper theory development (e.g., Frombrun et al., 2000; Lewellyn, 2002; Wartick, 2002). Since the mid-2000s, two research fields have dominated the study of corporate reputation, namely marketing and corporate communication. The concern of marketing with reputation stems from the strong relationship between reputation and the construct of branding, which is a central notion in this field. In the last decade of the previous century, the focus of marketing shifted from the product level to the brand and organisational levels. This shift was caused by the growing similarity of products due to technical developments and globalisation, which challenged marketers to find other ways to distinguish their company from competitors (Vargo \& Lusch, 2004). Corporate communication, influenced by organisational theories on identity and image (e.g., Birkigt \& Stadler, 1986) and the socio-economic perspective on organisations as presented by stakeholder theory (Freeman, 1984), developed from a field primarily concerned with public relations to the study of stakeholder management through communication. ${ }^{1}$

\section{Definitional issues}

As stated earlier, there are many definitions of reputation. An important source of the definitional confusion is disagreement between scholars on the distinction between the

\footnotetext{
${ }^{1}$ Not all scholars view marketing and corporate communication as separate fields of study. With the growing attention on and shared interest in corporate reputation and branding, scholars from both sides are building on theories from both sides. E.g., Balmer and Greyser plea for a corporate marketing umbrella to synthesize corporate level concepts, including corporate communication (Balmer \& Greyser, 2006).
} 
concepts of identity, image and reputation. Very roughly, this disagreement can be traced back to the various disciplines that have been involved in the study of these concepts. Not only do scholars from different disciplines identify different types of identity (e.g., organisational, corporate and brand identity, or actual, desired and communicated identity) and different types of image and reputation (e.g., organisational vs. corporate image), but the concepts are also used interchangeably (Whetten \& Mackey, 2002; Wartick, 2002; Barnett et al, 2006; Micelotta \& Raynard, 2011). This lack of consensus means that, for instance, the definition of identity or reputation by some scholars would be referred to as image by others. Similarly, in organisational studies, the concepts of reputation, legitimacy and status are treated as being strongly related, partly overlapping and sometimes even similar, and efforts are made to differentiate these concepts (Bitektine, 2011; Deephouse \& Carter, 2005). Because of this definitional debate, it is impossible to synthesise the literature into a clear-cut, unambiguous description that finds agreement with all reputation scholars. In this chapter, I follow the definitions of Barnett et al. (2006) and Fombrun and Van Riel (2004) in their approach to corporate reputation. Based on their review of articles focusing on corporate reputation, Barnett et al. (2006) propose a definition that distinguishes this construct from 'image' on the one side and 'reputation capital' on the other. In their view, image should be seen as the observers' general perception of a company, as an 'awareness of', whereas corporate reputation involves judgment of that company by the stakeholder, as an 'assessment', often triggered by a firm’s past actions. Over time, these judgments contribute to the 'reputational capital' of the company, which is considered to be an 'economic and intangible asset' (Barnett et al. 2006). Renowned reputation scholars Fombrun and Van Riel add a second trait to the distinction between image and reputation: the degree to which the associations about the organisation are shared across various stakeholder groups. In their view, image refers to the perception of an organisation by an individual or a specific group of 
stakeholders, whereas reputation is the overall, more endurable evaluation (or assessment) of an organisation (Fombrun and Van Riel, 2004; Van Riel, 2010). ${ }^{2}$ As Deephouse and Jaskiewicz put it, "Reputation is the general level of favourability towards a firm held by its stakeholders; it indicates how much stakeholders admire and trust a firm relative to their expectations and to other firms” (Deephouse \& Jaskiewicz, 2013, p. 338). The conceptual difference with the evaluation of legitimacy as proposed by Bitektine (2011) and Deephouse and Carter (2005) is that legitimacy refers to the evaluation of a company or organisation as belonging to a certain known class or industry and as complying with social norms, whereas reputation refers to the evaluation of a company or organisation compared to other companies.

\section{The Corporate Reputation construct}

Despite the definitional issues, there is no dispute about the strong relationship between the constructs of identity, image and reputation. The identity of a company can be seen as its personality - the core values and beliefs that organisational members see as central, distinctive and enduring (Albert \& Whetten, 1985). This personality is expressed by behaviour, communication and visual symbols (Birkigt \& Stadler, 1986; Van Riel \& Balmer, 1997), which are observed or experienced directly by stakeholders and/or indirectly through peers and media coverage (Fombrun \& Van Riel, 2004; Cornelissen, 2011; Van Riel, 2010). Chains of impressions and associations develop into an image. Because stakeholders pay attention to those aspects of an organisation that are relevant to them, the perception of a company held by employees can differ from the perception held by, e.g., customers or suppliers (Lemmink, Schuijf \& Streukens, 2003; Van Riel, 2010). Therefore, an organisation

\footnotetext{
${ }^{2}$ The concepts of corporate identity, corporate image and reputation are also related to the marketing notion of branding. In this chapter, I view reputation as the assessment of the firm by stakeholders and branding as the efforts of the firm to communicate its relevant identity characteristics.
} 
can have different images. Over time, these images can develop into an opinion about the firm's ability to meet the stakeholder's expectations and needs. This opinion is not solely based on the actions of the company itself. Part of the assessment is based on what stakeholders know of the type of firm, the industry or the country of origin, which codetermine what stakeholders expect from the company and provide legitimacy to the company’s actions (Van Riel, 2010, 2012; Cornelissen, 2011; Bitektine, 2011). If this evaluation is shared by multiple stakeholders and across stakeholder groups, it becomes increasingly endurable. By then, it has developed into a reputation (Van Riel, 2012). The simple description above suggests that the development of a company's image and reputation based on identity is a one-way process that can be largely controlled by the company in question. In reality, the process is much more complex. Various scholars note that there is an interaction effect between identity, image and reputation (e.g., Van Riel \& Balmer, 1997; Cornelissen, 2011). This effect is caused by the efforts of a company to either live up to the expectations of stakeholders or to challenge them in the case of a negative reputation. Furthermore, the overall reputation of a company can positively or negatively influence the opinions of individuals. With respect to the level of control over image and reputation, both are influenced by the behaviour of the company and by its communication (Birkigt \& Stadler, 1986; Cornelissen, 2011; Van Riel, 2012) but also by what the stakeholders hear from others. Up until 20 years ago, the company itself was the most important source of information and could (to some extent) control content and the amount and speed of distribution. With the emergence of the internet and social media, however, the importance of the company as a source of information has rapidly decreased. Because these technologies facilitate stakeholders' search for information and the sharing of knowledge and experiences, they present both a huge threat (loss of control) and a huge opportunity (ease of access) for companies (Blombäck \& Craig, 2014). Stakeholders have developed from being the receivers 
of information to being the co-creators of reputation (Cornelissen, 2011; Parmentier, 2011).

This development includes the internal stakeholders because they also use the internet and social media. Employees distribute their own information about their organisation to external stakeholders through all types of electronic platforms (Cornelissen, 2011). Hence, reputation building is a very dynamic, interactive process and reputation management is a matter of careful planning, meticulously keeping track of issues that may become a hazard to the reputation and immediately responding whenever reputation is challenged. Reputation building focuses on the relationship with both internal and external stakeholders and aims at creating alignment with the company’s values and goals (Van Riel, 2012).

\subsection{Antecedents of corporate reputation}

Because reputation is a cumulated evaluation across stakeholder groups, it is multidimensional by nature. However, individual stakeholders can only evaluate an organisation using the aspects that they know and that are relevant to them (Lemmink, Schuijf \& Streukens, 2003; Van Riel, 2010, 2012). Because different stakeholders or stakeholder groups have different interests, an organisation will be evaluated on different characteristics. However, not all perceptions held by single stakeholders or groups are equally important to the construction of reputation and various scholars have attempted to identify those that are. Although the resulting models show some differences caused by, e.g., different definitions or cultural differences between the countries in which these perceptions were developed, they also show large similarities (Ponzi, Fombrun \& Gardberg, 2011). It would go beyond the purpose of this chapter to discuss the differences between the various models. I borrow the dimensions of corporate reputation from a conceptual model that was developed by scholars from The Reputation Institute in New York. Based on earlier reputation literature and both quantitative and qualitative research, they identified seven categories of characteristics that can be attributed to a company by stakeholders and that drive a positive or negative 
assessment of that company (Fombrun \& Van Riel 2004; Ponzi et al. 2011). Table 1 shows these categories and their underlying attributes.

\section{- $\quad$ Insert Table 1 about here -}

The drivers in the right column of Table 1 represent the multidimensional nature of reputation. The interests of the different stakeholder groups can be recognised, from consumers and prospective applicants to interest groups or the public in general. The attributes in the left column represent the antecedents of a favourable image or an overall favourable reputation. The dimensions in this model and in an earlier version have been applied to research purposes by various scholars and to the reputation measurement of large companies in dozens of countries ${ }^{3}$. However, this and similar models have their limitations, and some of these are important to mention in the context of family firms. I will go into this concern in the paragraph about future research.

\subsection{Consequences of a good reputation}

Scholars and practitioners generally agree that a good reputation generates many advantages for an organisation (e.g., Fombrun \& Shanley, 1990; Fombrun \& Van Riel, 2004). One of these advantages is the ability to attract increasing numbers of highly skilled employees. Several studies show that a prospective applicant's assessment of an organisation plays a key role in his or her application intentions and application decisions (e.g., Gatewood, Gowan \& Lautenschlager, 1993; Turban and Cable, 2003; Lemmink, Schuijf, \& Streukens, 2003). Another advantage of a favourable reputation is its positive effect on sales. Decades of study

\footnotetext{
${ }^{3}$ The outcome is expressed by a reputation score (scale 1-100) that informs companies about their relative standing. The score is the cumulative result of the scores for separate drivers.
} 
on the effect of image/reputation on the purchase intentions of consumers provide evidence for this relationship (e.g., Poiesz, 1989; Wright and Fill, 2001). Other reported consequences of a good reputation are the willingness of investors or creditors to lend money to a company and the willingness to act as an ambassador by providing recommendations or general verbal support (Ponzi et al. 2011; Van Riel, 2010, 2012). These advantages give a company a better chance of survival in times of crisis (Dyer \& Whetten, 2006; Van Riel, 2012). In recent family firm literature, the non-economic advantages of reputation are highlighted by identifying reputation as an important socioemotional wealth goal that provides affective value to family members (e.g., Deephouse \& Jaskiewicz, 2013). This and other approaches to reputation in family firm studies will be discussed in the next paragraph.

\section{Reputation research in the field of family firms}

Very few studies on family firms focus on reputation or the related topic of image as their key concept. There is only one article on family firms that I know of that builds on a conceptual model of reputation as outlined in Table 1 (Binz, Hair Jr., Pieper \& Baldauf, 2013). However, there is literature in this field that touches upon reputation from a related theoretical perspective, so therefore the scope of this chapter is broadened to include some family firm studies that examine image and reputation from a marketing and managerial perspective. For discussion, I classify the articles into three groups following the outline of the theory as presented in this chapter.

The first group of articles focuses on the antecedents of reputation. I discuss five examples of articles that examine the image/reputation of family firms from the external perspective by looking at the perceptions of family firms held by (external) stakeholders and at how family firms are evaluated compared to non-family firms. The second group focuses on the consequences for the owning family. In these articles, the theoretical lenses of socioemotional 
wealth and social identity are used to explain why family firms are concerned with reputation management. The third group uses the marketing perspective by investigating the opportunities and options available to family firms using their family firm identity as a brand, thus capitalising on an assumed positive generic reputation for family firms held by external stakeholders. $^{4}$

a. Reputation as the stakeholders' assessment of the family firm compared to non-family firms

Carrigan and Buckley (2008) explored the perceptions of family firms held by consumers. They interviewed 19 respondents in the UK and Ireland. Their respondents attribute a range of positive qualities to family firms and find the overall image of a family firm appealing. In a study by Orth and Green (2009) on consumer loyalty to family versus non-family firms, consumers were questioned on specific topics that were expected to contribute to the consumers’ perception of differences between family and non-family firms. Although the questions were limited to specific topics, the study provides evidence of a more positive score for family firms compared to non-family firms with respect to service orientation, the cooperation of personnel and consumer confidence but a more negative score with respect to product range and price/quality ratio.

In this category, we also find the only study on the topic of family firm reputation that uses a conceptual model of reputation as presented in the previous paragraph. Binz et al. (2013) use a quantitative approach to study the perceptions of consumers of family firms compared to non-family firms. An earlier version of the reputation model was used to design the survey. A factor analysis of the results showed a factor structure that differed from the model. Therefore, the model was revised from a six-dimensional model into a two-dimensional

\footnotetext{
${ }^{4}$ The classification of the articles was made for reasons of clarity and based on the primary focus of the articles. One could argue that some of the articles could belong in at least two groups.
} 
model with 'relational qualities' and 'business qualities' as drivers. The authors found that the promotion of the 'family firm' status leads to a higher preference for the products of the firm, but this preference is primarily driven by positive associations with the relational qualities of family firms.

Most of the externally oriented studies address consumers as stakeholders. Few studies examine the attraction of family firms as employers. Covin (1994) studied the effect of the family firm identity ${ }^{5}$ on graduate students. She found that her respondents, especially females, were more attracted to family firms than to non-family firms. A study by Michael-Tsabari, Lavee and Hareli (2008), however, shows different results. Applicants applying for a managerial position had negative associations with working for a family firm and as a result showed no interest.

\section{b. Reputation as a managerial goal}

The literature in the previous paragraph focuses on reputation as an assessment by external stakeholders. In this paragraph, I will discuss the literature that focuses on how reputational concerns affect managerial decisions.

Colli (2012) illustrates how family firms throughout history have treated their reputation as an invaluable asset, a measure of performance and something that should be guarded at all times. Other articles in this group take this idea a step further by using a specific theoretical perspective. Differences in behaviour between family and non-family firms are explained by highlighting the consequences of a good or bad reputation for the family. A central idea here is that the firm reputation, whether good or bad, has a direct effect on the reputation of the

\footnotetext{
${ }^{5}$ Without denying the definitional discussion about family firms or their heterogeneity, I use this term as an umbrella term to distinguish the firms that were presented as a family firm to the respondents from the non-family firms.
} 
owning family, which is a consequence that, unlike other consequences of reputation, is specific to family firms. Zellweger, Nason, Nordqvist and Brush (2011), for instance, present an organisational identity perspective to explain the concern of family firms with reputation. This concern is based on the strong identity fit between the family and the firm. The stronger this fit, the stronger the concern for reputation. The need for a strong identity fit is a product of the visibility of the family as the controlling coalition, the intentions to pass the firm on to the next generation (creating a long-lasting relationship between the family and the firm) and the attractiveness of the firm to the family (the degree to which the firm enables self-

enhancement). This perspective explains the family firm's attention to reputation, but it also accounts for the heterogeneity of family firms because of their different scores on the three factors (Zellweger et al, 2011).

The reputation model summarised in Table 1 contains ‘citizenship' as one of the behavioural drivers of reputation. Dyer and Whetten (2006) compare the degree to which family and nonfamily firms demonstrate citizenship through their socially responsible behaviour. Data from the S\&P 500 from 1991-2000 were used. The findings show that although family firms are not likely to engage in more socially responsible activities than non-family firms, they are likely to be less socially irresponsible. Based on social identity theory, the authors argue that this difference is due to a concern about the family reputation and - as a consequence - the family assets and wealth. A similar line of thought was developed by Berrone, Cruz, GomezMejia and Larraza-Kintana (2010). In an empirical study of 194 public firms in the United States, they compare the environmental performance of family to nonfamily firms. Their findings show that family firms behave in a more environmentally friendly manner. They conclude that family firms are more inclined to respond to institutional pressures due to concern for their reputation; this applies especially to those firms with strong roots in the region because the family members are an easy target for community anger. A positive 
reputation of the firm contributes to the socioemotional wealth of the family, thus family firm owners make decisions that support the reputation or prevent reputational damage. Hence, concern for reputation explains managerial decisions that cannot be explained by financial motives. Other examples of this approach are the articles by Gómez-Mejía, Cruz, Berrone and De Castro (2011) and Deephouse and Jaskiewicz (2013). In the latter, the authors draw from socioemotional wealth and social identity theory to propose that family members will put more effort into reputation management. Therefore, family firms will have a better reputation than non-family firms. They find evidence for this proposal in a sample of 197 large firms from eight countries. Similarly, Memili, Eddleston, Kellermans, Zellweger, and Barnett (2010) show that family ownership is positively related to family firm image. ${ }^{6}$

\section{c. How family firms (can) communicate to enhance their reputation}

The articles in the previous paragraph treat concern for reputation as an explanatory factor for the behaviour of family firms, especially with regards to the pursuit of non-financial goals. However, apart from behaviour, reputations are built and strengthened by communication (Birkigt \& Stadler 1986, Van Riel \& Balmer, 1997; Apéria, Simcic Brønn \& Schultz, 2004; Van Riel, 2012). Consistent with the notion that reputations can develop on a corporate level but also on a group or industry level (Cornelissen, 2011; Van Riel, 2012), various articles discuss the potential of deploying the (assumed favourable) family business reputation by communicating the family firm status to the stakeholder. An example of this discussion is the article by Craig, Dibrell and Davis (2008), who suggest that family firms can persuade

\footnotetext{
${ }^{6}$ Memili et al. (2011) draw from organizational identity theory to define image. In this definition, image represents the way organizational members believe others see the organization and how organizational leaders would like outsiders to see the organization. This definition is different from that in this chapter. Nevertheless, I include this article because the authors explain the importance of (organizational) image for reputation, which is defined as the perspective of the external stakeholders, comparable to the definitions of image and reputation that are used in this chapter.
} 
customers to make purchasing decisions by actively communicating their family firm identity. Two other scholars who have been active in this area are Blombäck and Botero. Their joint theoretical work on this topic aims to show the potential of looking at family businesses as a brand (Blombäck and Botero, 2013). The line of reasoning here is that customers have positive associations with family owned businesses. Therefore, active communication by family firms about their family ownership evokes positive perceptions about the quality of their products and service, hence creating a competitive advantage. The authors present this argument as offering the potential to advance our understanding of the success factors of family firms.

Other articles from this perspective explore how firms use their identity as a family firm in their communication. Micelotta and Raynard (2011) examine the branding strategies of established family firms by analysing their websites. They identify three strategies that family firms use to communicate their family firm status. Botero, Thomas, Graves and Fediuk (2013) analysed over a thousand websites of family firms to explore if, how and where family firms communicate their identity on their website and how the differences are related to firm characteristics, such as age, country and industry.

What have we learned so far from this literature? The picture that appears to emerge from all three groups of articles is that family firms have a positive reputation: the first group establishes how family firms are assessed compared to non-family firms, the second group provides an explanation for this assessment by the higher effort of the owning family and the third group suggests how this assumed favourable reputation is used in branding strategies. However, there is reason for criticism. It is clear that the family firm literature from this perspective is still very limited both in number and in variety. Many questions remain unanswered. In the next section, I will identify the gaps in the current literature and explore possible directions for future research. 


\section{d. Future research directions}

Table 1 contains the antecedents of a good reputation as borrowed from Reptrak ${ }^{\mathrm{TM}}$ (Van Riel, 2012). Because the identification of these antecedents was based on the assessments of large and/or listed companies in various countries and from various industries, it is not clear whether they are valid for all companies, small and medium sized companies in particular. This is an important limitation of this model because the majority of the family firms across the world are small- and medium-sized enterprises. Second, ‘family firm’ was not a variable that was taken into account during the model's development. In the case of family firms, it is conceivable that their reputation is based on additional or other drivers, such as the behaviour of family members or the associations that stakeholders may have with family firms in general. For example, stakeholders could have different expectations for family firms than for non-family firms. According to Van Riel (2012), for instance, the economic drivers of the reputation model (such as performance and product quality) are usually found to be more important for reputation than the drivers representing socially responsible behaviour (such as citizenship and workplace environment). In contrast, Binz et al. (2013) found that the higher preference for family firms was primarily driven by associations with the 'relational qualities' instead of 'business qualities' (or economic drivers, in the terms of Van Riel, 2012). This finding supports the idea that stakeholders pay attention to other dimensions in the case of family firms and it raises the question as to whether there are dimensions relevant to family firms that are not included in the current models. So an important theoretical goal for future research would be to develop a reputation model that is valid for family firms.

To extend this model, another relationship that deserves attention is that between reputation and its consequences, which has not been thoroughly studied in the case of family firms. There could be more, less or different consequences for the reputations of family firms or of 
certain types of family firms. As we have seen from the literature in the previous section, at least one possible additional consequence is reputation's effect on the socioemotional wealth of the owning family.

Regarding the first group of articles, although it appears that stakeholders tend to judge a family firm positively, these results are not unambiguous. This ambiguity may be due to differences in the size of the firms involved, in the industry or, for that matter, in the country (Blombäck \& Botero, 2013; Dyer \& Whetten, 2006), or to differences in ownership structure or managerial orientation. There has not been much attention paid to this heterogeneity to date. The respondents of Carrigan and Buckley (2008) refer to family firms as small firms, so it is not clear if their perceptions are based on the family firm characteristics or on size. Furthermore, the respondent range of the articles is limited. Of all of the stakeholders that are identified by Freeman (1984), including business-to-business customers, government, special interest groups and so forth, and that can be important to family firms, only two are involved in this line of research, and a large portion of the attention goes to consumers. Just a few articles address the employer reputation of family firms by zooming in on applicants. So studies that address the reputation of family firms, whether a specific firm or in general, should be extended to all of the relevant stakeholders and should take the heterogeneity of family firms into account.

The second group of articles teaches us that the inextricable connection between the family identity and the firm identity leads to a heightened concern for reputation and thus to managerial choices that have no apparent financial goal. In other words, the reputational lens can explain firm behaviour that is difficult to explain from a financial point of view. However, it can be questioned whether a deliberate action only based on reputation considerations is effective (Dowling \& Moran, 2012). The positive effect on reputation that was found in these articles, for example, may also be explained by the perceptions of stakeholders about family 
firms and not by managerial efforts, because the companies that were selected were easily recognisable as family firms by their names (e.g., Deephouse \& Jasciewicz, 2013). Second, the empirical evidence in these articles is confined to socially responsible behaviour, which belongs to the antecedent 'citizenship' in Table 1 . However, the reputation construct is multidimensional, so future research should reveal whether the concern of the family for a good reputation can explain firm behaviour on other terrains (antecedents) as well, if this differs from the behaviour of non-family firms and if there are differences between family firms. Finally, although these articles offer explanations for firm behaviour, they are missing the voice of the family behind the firm. Future research should aim to confirm the explanations offered in the studies by collecting empirical evidence from the families in charge.

The third group of articles about marketing communication suggests that family firms can or should use this part of their identity as a quality brand by communicating it more actively to stakeholders. The underlying assumptions are that family firms in general have a good reputation and that communicating this firm characteristic is beneficial. However, these assumptions have not been thoroughly explored, so future research should investigate whether they are true, under which conditions and how the relationship between a family identity and reputation works. With respect to the first question, the first group of articles showed that the empirical evidence for a positive assessment is limited to just two groups of stakeholders and that there is no insight into the effect of differences between family firms. The literature in this third group shows that family firms deploy different strategies to communicate their identity and that these differences are related to firm characteristics. These findings could be extended by studies that explore the effect of these different strategies on stakeholders and identify which content should be communicated about the firm to which stakeholder groups to enhance a positive assessment. Aside from this need, the studies are limited to communication through websites. What other communication strategies or tools do family firms use to 
enhance their reputation and how effective are they? Last but not least, what motivates entrepreneurs to adopt a particular strategy? As with the second group of articles, the voice of the family is conspicuously missing in this literature to date.

Is it worthwhile pursuing this line of research? Considering the breadth of the corporate reputation construct and the issues in family firms that can have an effect on their reputation, one could say that the family firm field has not even begun to explore this avenue. The lens of corporate reputation can provide an alternative explanation for family firm behaviour and success. Family firm studies encompass all types of behaviour from both the firm and the family, including ownership transition, acquisition, diversification, portfolio entrepreneurship, internationalisation, etc. (e.g., Habbershon \& Pistrui, 2002; Nordqvist, Wennberg, Baù \& Hellerstedt, 2013). The corporate reputation lens can contribute to these studies. What is, for example, the effect on the reputation of the family firm in the case of a merger (either with a family or a non-family firm)? In the other direction, what is the effect of reputation (considerations) on these types of strategies? However, above all, the literature suggests that management and reputation have a very close relationship in family firms; is the nature of this relationship really different from non-family firms? Any entrepreneur should be concerned with the firm's reputation considering the severe consequences in the case of its loss. In this chapter, I have discussed antecedents and consequences of a favourable corporate reputation. What follows logically is that this theory can also offer explanations for family firm failure. In the case of failure after succession, for instance, perhaps part of the explanation can be found in a decline in reputation due to a temporary lack of reputation management.

In depth understanding of the reputation of family firms, its antecedents and consequences also contributes to the study of the corporate reputation construct in general. How does a very visible and in other social contexts active owner influence the construction of a good firm 
reputation? Is this type of owner, for instance, able to control more of the communication and behaviour that provide clues to the stakeholder? To what extent do stakeholders use clues from other contexts to evaluate the firm? Are there, in other words, additional antecedents and consequences that should be included or at least considered when studying the reputation of a certain (type of) company?

Family firm practitioners benefit from these results through a better awareness and understanding of the importance of reputation management, their stakeholders' needs, what drives stakeholders' choices, the role of the family and the added value potentially stemming from their family firm identity. This knowledge will help them to manage their reputation more effectively, through both behaviour and communication.

Because of the complex and multidimensional nature of corporate reputation development, a cross disciplinary and multilevel approach is needed. Insights from, e.g., organisation theory, sociology, psychology, economics and communications can advance our knowledge of the reputation construct on the firm, group and individual level. Furthermore, I advocate for more attention to the qualitative approach. The majority of the empirical articles discussed in this chapter are based on quantitative methods, as are most studies in the family business field. Researchers in this field therefore argue for the greater use of this methodology to capture the complexity and dynamics of the family business (Nordqvist, Hall \& Melin, 2009). Additionally, in research on reputation in particular, it is the richness of the cognitive processes preceding judgment formation by stakeholders (Bitektine, 2011) that makes a qualitative approach so suitable because it enables the researcher to capture on a micro-level how these processes take place and why people behave as they do (Belk, Fischer \& Kozinets, 2013). This knowledge is specifically important because the aim is to identify the role of the family firm specific issues in the construction of reputation. 
The field of consumer psychology offers various methods for eliciting opinions and beliefs and determining their influence on decisions. Examples are the Laddering Technique and the Zaltman Metaphor Elicitation Technique (ZMET). The Laddering Technique can be described as a specific interviewing format that aims to identify value chains in consumer's minds. These chains demonstrate how consumers translate the attributes of a certain product or brand into personally held beliefs, thus explaining the reasons behind their choices (Reynolds \& Gutman, 1988). The ZMET is a multi-step method based on a combination of various techniques to identify metaphors that express how respondents perceive a certain topic (Zaltman \& Coulter, 1995; Belk, Fischer and Kozinets, 2013). Another example is the use of focus groups, a qualitative method that was also used to develop the Reptrak ${ }^{\mathrm{TM}}$ and its earlier version (Van Riel, 2012; Ponzi et al., 2011). On firm level, qualitative methods, such as interviewing and case studies, and techniques, such as content analysis, are also suitable for capturing the motives of managing families for their strategic and behavioural decisions that concern reputation. The relevance and suitability of case studies in the family business field in general is outlined by De Massis and Kotlar (2014).

\section{Conclusion}

Corporate reputation is an understudied topic in in the field of family firms. This negligence may be caused by a definitional dispute regarding reputation among scholars from different disciplines, but the fact is that only a few studies discuss this or a closely related topic in the context of family firms. In this chapter, I have identified three streams: the external stakeholder perspective, the internal managerial perspective and the marketing/branding perspective. What we are missing is a conceptual model that is proven valid for family firms. The development of such a model is one of the challenges for future research. Although there are both theoretical and empirical articles, the entrepreneur as a source of information or focus 
of attention is invisible, as is the possible effect of differences between family firms in these studies. Future research can fill these gaps, but it should be conducted on multiple levels and should cover the broad spectrum of the reputation construct. To contribute to the family firm field, research questions should be aimed at the identification of family firm specific reputation issues. Therefore, I suggest the use of qualitative methods to collect empirical evidence on all levels in addition to the quantitative and theoretical approaches offered in most of the presented studies. 


\section{References}

Albert, S. and Whetten, D. A. (1985), 'Organizational identity', in Staw, B. M. and Cummings, L. L. (eds), Research in Organizational Behavior, Volume 7, Greenwich, CT: JAI Press, pp. 26395.

Aperia, T., Simcic Brønn, P. and Schultz, M. (2004), 'A reputation analysis of the most visible companies in the scandinavian countries', Corporate Reputation Review, 7 (3), 218-30.

Balmer, J. M. T. and Greyser, S. A. (2006), 'Corporate marketing: Integrating corporate identity, corporate branding, corporate communications, corporate image and corporate reputation', European Journal of Marketing, 40 (7), 730-41.

Barnett, M. L., Jermier, J. M. and Lafferty, B. A. (2006), 'Corporate reputation: the definitional landscape’, Corporate Reputation Review, 9 (1), 26-38.

Belk, R., Fischer, E. and Kozinets, R. V. (2013), Qualitative Consumer and Marketing Research, Los Angeles, CA: SAGE Publications Inc.

Berrone, P., Cruz, C. C., Gomez-Mejia, L. R. and Larraza-Kintana, M. (2010), 'Socioemotional wealth and corporate response to institutional pressures: do family-controlled firms pollute less?’, Administrative Science Quarterly, 55 (1), 82-113.

Binz, C., Hair Jr, J. F., Pieper, T. M. and Baldauf, A. (2013), 'Exploring the effect of distinct family firm reputation on consumers’, Journal of Family Business Strategy, 4 (1), 3-11.

Birkigt, K. and Stadler, M. M. (1986), Corporate Identity: Grundlagen, Funktionen, Fallspielen, Landsberg an Lech, Germany: Verlag Moderne Industrie.

Bitektine, A. (2011), 'Toward a theory of social judgements of organizations: the case of legitimacy, reputation and status', Academy of Management Review, 36 (1), 151-79.

Blombäck, A. and Botero, I. C. (2013), Reputational capital in family firms: understanding uniqueness from the stakeholder point of view', in Smyrnios, K. X., Poutzouris P. Z. and Goel, S. (eds), Handbook of Research on Family Business, Second Edition, Cheltenham, UK and Northampton, MA, USA: Edward Elgar Publishing Inc., Ch. 28.

Blombäck, A. and Craig, J. (2014), 'Marketing from a family business perspective', in Melin, L., Nordqvist, M. and Sharma, P. (eds), The SAGE Handbook of Family Business Studies, London: Sage Publications Ltd., pp. 423-41.

Botero, I .C., Thomas, J., Graves, C. and Fediuk, T. A. (2013), 'Understanding multiple family firm identities: an exploration of the communicated identity in official websites', Journal of Family Business Strategy, 4 (1), 12-21.

Brown, T. J., Dacin, A., Pratt, M. G. and Whetten, D. A. (2006), 'Identity, intended image, construed image, and reputation: an interdisciplinary framework and suggested terminology', Journal of the Academy of Marketing Science, 34 (2), 99-106.

Carrigan, M. and Buckley, J. (2008), 'What’s so special about family business? An exploratory study of UK and Irish consumer experiences of family businesses', International Journal of Consumer Studies, 32 (6), 656-66. 
Colli, A. (2012), 'Contextualizing performances of family firms: the perspective of business history', Family Business Review, 25 (3), 243-57.

Cornelissen, J. (2011), Corporate Communication. A Guide to Theory and Practice, London: Sage Publications Ltd.

Covin, T .J. (1994), 'Profiling preference for employment in family-owned firms', Family Business Review, 7 (3), 287-96.

Craig, J. B., Dibrell, C. and Davis, P. S. (2008), 'Leveraging family-based brand identity to enhance firm competitiveness and performance in family businesses', Journal of Small Business Management, 46 (3), 351-71.

Deephouse, D. L. and Carter, S. M. (2005), 'An examination of differences between organizational legitimacy and organizational reputation’, Journal of Management Studies, 42 (2), 329-60.

Deephouse, D. L. and Jaskiewicz, P. (2013), 'Do family firms have better reputations than nonfamily firms? An integration of socioemotional wealth and social identity theories', Journal of Management Studies, 50 (3), 337-60.

De Massis, A. and Kotlar, J. (2014), 'The case study method in family business research: Guidelines for qualitative scholarship’, Journal of Family Business Strategy, 5 15-29.

Dowling, G. R. and Moran, P. (2012), ‘Corporate reputations: built in or bolted on?’, California Management Review, 54 (2), 25-42.

Dyer, W. and Whetten, D. A. (2006), 'Family firms and social responsibility: preliminary evidence from the S\&P 500', Entrepreneurship Theory and Practice, 30 (6), 785-802.

Fombrun, C. J. and Shanley, M. (1990), 'What's in a name? Reputation building and corporate strategy’, Academy of Management Journal, 33 (2), 233-58.

Fombrun, C. J. and Van Riel, C. B. M. (2004), Reputatiemanagement, Amsterdam: Pearson Education Benelux.

Fombrun, C. J, Gardner, N. A. and Sever, J. M. (2000), 'The reputation quotient: a multi-stakeholder measure of corporate reputation', The Journal of Brand Management, 7 (4), 241-55.

Freeman, R. E. (1984), Strategic Management: A Stakeholder Approach, Boston, MA: Pitman.

Gatewood, R. D., Gowan, M. A. and Lautenschlager, G. T. (1993), 'Corporate image, recruitment image and initial job choice decisions’, The Academy of Management Journal, 36 (2), 41427.

Gomez-Mejia, L. R., Cruz, C. C., Berrone, P. and De Castro, J. (2011), 'The bind that ties: socioemotional wealth preservation in family firms', The Academy of Management Annals, 5 (1), 653-707.

Habbershon, T. G. and Pistrui, J. (2002), 'Enterprising families domain: family-influenced ownership groups in pursuit of transgenerational wealth’, Family Business Review, 15 (3), 223-37.

Kashmiri, S. and Mahajan, V. (2010), 'What's in a name? An analysis of the strategic behavior of family firms', International Journal of Research in Marketing, 27 (3), 271-80. 
Lemmink, J., Schuijf, A. and Streukens, S. (2003), 'The role of corporate image and company employment image in explaining application intentions', Journal of Economic Psychology, 24 (1), 11-15.

Lewellyn, P. G. (2002), 'Corporate reputation: focusing the zeitgeist', Business and Society, 41 (4), 446-55.

Memili, E., Eddleston, K. A., Kellermans, F. W., Zellweger, T. M. and Barnett, T. (2010), 'The critical path to family firm success through entrepreneurial risk taking and image', Journal of Family Business Strategy, 1 (4), 200-209.

Micelotta, E. and Raynard, M. (2011), 'Concealing or revealing the family? Corporate brand identity strategies in family firms’, Family Business Review, 24 (3), 197-216.

Michael-Tsabari, N., Lavee, Y. and Hareli, S. (2008), 'Stereotypes of family businesses and their role in choosing a workplace', paper presented at the 8th Annual IFERA Conference.

Nordqvist, M., Hall, A. and Melin, L. (2009), 'Qualitative research on family businesses: the relevance and usefulness of the interpretive approach', Journal of Management and Organization, 15, 294-308.

Nordqvist, M., Wennberg, K., Baù, M. and Hellerstedt, K. (2013), 'An entrepreneurial process perspective on succession in family firms’, Small Business Economics, 40 (4), 1087-1122.

Orth, U. R. and Green, M. T. (2009), 'Consumer loyalty to family versus non-family business: the roles of store image, trust and satisfaction', Journal of Retailing and Consumer Services, 16 (4), 248-59.

Parmentier, M. A. (2011), 'When David met Victoria: forging a strong family brand', Family Business Review, 24 (3), 217-32.

Poiesz, T. B. C. (1989), 'The image concept: its place in consumer psychology', Journal of Economic Psychology, 10 (4), 457-72.

Ponzi, L. J., Fombrun, C. J. and Gardberg, N. A. (2011), 'RepTrak ${ }^{\mathrm{TM}}$ Pulse: conceptualizing and validating a short-form measure of corporate reputation', Corporate Reputation Review, 14 (1), 15-35.

Reynolds, T. J. and Gutman, J. (1988), 'Laddering theory, method, analysis, and interpretation', Journal of Advertising Research, 28 (1), 11-31.

Turban, D. B. and Cable, D. M. (2003), 'Firm reputation and applicant pool characteristics', Journal of Organizational Behavior, 24 (6), 733-51.

Van Riel, C. B. M. (2010), Identiteit en imago, The Hague: Academic Service, Sdu Uitgevers bv.

Van Riel, C. B. M. (2012), The Alignment Factor. Leveraging the Power of Total Stakeholder Support, Abingdon: Routledge..

Van Riel, C. B. M. and Balmer, J. M. T. (1997), 'Corporate identity: the concept, its measurement and management', European Journal of Marketing, 31 (5/6), 340-55.Vargo, S. and Lusch, R. (2004), 'Evolving to a new dominant logic for marketing', Journal of Marketing, 68 (1), 117. 
Wartick, S. L. (2002), 'Measuring corporate reputation, definition and data', Business and Society, 41 (4), 371-92.

Whetten, D. A. and Mackey, A. (2002), 'Social actor conception of organizational identity and its implications for the study of organization reputation’, Business and Society, 41 (4), 393-414.

Wright, H. and Fill, C. (2001), 'Corporate images, attributes and the UK', Corporate Reputation Review, 4 (2), 99-110.

Zaltman, G. and Coulter, R. H. (1995), 'Seeing the voice of the customer: metaphor-based advertising research’, Journal of Advertising Research, 35 (4), 35-51.

Zellweger, T. M., Nason, R. S., Nordqvist, M. and Brush, C. G. (2011), 'Why do family firms strive for nonfinancial goals? An organizational identity perspective', Entrepreneurship Theory and Practice, 37(2), 229-48. 
Table 13.1: Overview of attributes driving reputation (borrowed from the Reptrak ${ }^{\mathrm{TM}}$, a conceptual model of reputation developed by the Reputation Institute)

\section{Attributes contributing to Corporate Reputation \\ Categories/drivers}

High quality of products and services; good value for money; company Products \& services stands behind the products; the product/service meets customers' needs.

\begin{tabular}{ll}
\hline Innovative; first to market; adapts quickly to change Innovation orientation
\end{tabular}

Profitable; high-performing; growth prospects Performance

Open and transparent; behaves ethically; fair in the way it does Governance business

\begin{tabular}{ll}
\hline $\begin{array}{l}\text { Environmentally responsible; supports good causes; positive influence } \\
\text { on society }\end{array}$ & Citizenship \\
\hline $\begin{array}{l}\text { Rewards employees fairly; concern for employees; offers equal } \\
\text { opportunities }\end{array}$ & Workplace environment \\
\hline $\begin{array}{l}\text { Well organized; strong and appealing leader; excellent management; } \\
\text { clear vision }\end{array}$ & Leadership \\
\hline
\end{tabular}

